\title{
BLOOD SUGAR STUDIES ON PREMATURE BABIES*
}

\author{
BY \\ O. CONOR WARD \\ From the Department of Child Health, Alder Hey Children's Hospital, Liverpool \\ (RECEIVED FOR PUBLCATION JANUARY 26, 1953)
}

The blood sugar has been extensively studied in normal infants. There is a great variation in the published results (Ketteringham and Austin, 1938; Hartman and Jaudon, 1937). Norval, Kennedy and Berkson (1949) found mean fasting values of $56 \mathrm{mg}$. on the first day, $54.9 \mathrm{mg}$. On the second day, $57 \mathrm{mg}$. On the third day and a gradual rise to $69 \mathrm{mg}$. on the fifth day. All workers have found that the results vary over a very wide range. Clement Smith (1951) states that the range is so wide that a 'normal' figure is of very little value.

Similar investigations on premature infants have been less numerous, especially in the first two days of life. Van Creveld (1929) found levels of $51 \mathrm{mg}$., $31 \mathrm{mg}$. and $60 \mathrm{mg}$. on the second day. Miller and Ross (1940) found a mean value of $32 \mathrm{mg}$. on the first day, with a range of $19 \mathrm{mg}$. to $44 \mathrm{mg}$. Norval (1950) found levels of $45 \mathrm{mg}$. and $53 \mathrm{mg}$. on the first and second days, with a continuous rise until the fourteenth day. She also performed serial readings on four infants during the first day of life and found a rapid fall over the first four hours, a slower fall for another eight to 12 hours and a slight rise during the following 12 hours. Over the next day the levels rose in two of the infants and fell in the other two.

\section{Material}

One hundred and fifty-four determinations were made on 21 infants weighing $5 \mathrm{lb} .8 \mathrm{oz}$. (2,500 g.) or under at birth. Only four of the infants received feeds during the period of observation. These infants received $5 \%$ glucose in quantities approximating to $0.4 \mathrm{~g}$. per $\mathrm{kg}$. An effort was made to collect a specimen from each child every six hours for the first 48 hours. A number of infants died before the 48-hour period was completed. The first specimen was taken from the placental end of the umbilical cord. Subsequent specimens were obtained by heel-prick. The Nelson-Somogyi method was used. The object of the investigation was to determine the blood sugar levels of premature infants in

\footnotetext{
- Based on material used for an M.D. thesis.
}

the first two days of life, with particular reference to the effect of birth weight, jaundice, neonatal distress and survival. The liver glycogen level was determined after death in 10 infants to ascertain the effect of starvation. The method used was that of Eufinger (1932).

\section{Results}

The mean cord-blood sugar was $66 \mathrm{mg}$. per 100 $\mathrm{ml}$. with a range of $40 \mathrm{mg}$. to $140 \mathrm{mg}$. The mean post-natal level was $45 \mathrm{mg}$., with a range of $16 \mathrm{mg}$. to $90 \mathrm{mg}$. The most striking characteristic noted was the extreme variability of the blood sugar level. Wide fluctuations occurred in the series as a whole and in the individual curves.

There was practically no difference between the mean levels on the first and second days, $44 \mathrm{mg}$. and $45 \mathrm{mg}$. respectively. The readings were divided into six-hour groups from birth onwards (Table 1).

TABLE 1

RELATIONSHIP BETWEEN BLOOD SUGAR AND AGE

\begin{tabular}{|c|c|c|c|c|c|}
\hline $\begin{array}{c}\text { Age } \\
\text { (hours) }\end{array}$ & $\begin{array}{l}\text { No. of } \\
\text { Deter- } \\
\text { minations }\end{array}$ & Mean & $\begin{array}{l}\text { Standard } \\
\text { Deviation }\end{array}$ & $\begin{array}{l}\text { Highest } \\
\text { Level }\end{array}$ & $\begin{array}{l}\text { Lowest } \\
\text { Level }\end{array}$ \\
\hline $\begin{array}{l}0-6 \\
12 \\
18 \\
24 \\
30 \\
36 \\
42 \\
48\end{array}$ & $\begin{array}{l}20 \\
23 \\
23 \\
14 \\
15 \\
10 \\
14 \\
14\end{array}$ & $\begin{array}{l}47 \cdot 4 \\
45 \cdot 1 \\
43 \cdot 2 \\
42 \cdot 8 \\
44 \cdot 2 \\
40 \cdot 8 \\
45 \cdot 7 \\
50 \cdot 0\end{array}$ & $\begin{array}{l}28 \cdot 3 \\
20 \cdot 6 \\
18 \cdot 4 \\
15 \cdot 0 \\
25 \cdot 3 \\
11 \cdot 9 \\
17 \cdot 5 \\
17 \cdot 4\end{array}$ & $\begin{array}{r}72 \\
107 \\
62 \\
60 \\
90 \\
60 \\
78 \\
80\end{array}$ & $\begin{array}{l}26 \\
18 \\
15 \\
16 \\
18 \\
25 \\
18 \\
19\end{array}$ \\
\hline
\end{tabular}

There was no significant difference between the various age-groups, with one exception. The value of $50 \mathrm{mg}$. found in the final period is significantly higher than that found in the sixth period. It will be noted that the sixth period contains the smallest number of determinations.

No relationship was found between the blood sugar level and the birth weight (Table 2). The only groups which showed a significant difference were the $3 \mathrm{lb}$. to $3 \mathrm{lb}$. $15 \mathrm{oz}$. group and the $5 \mathrm{lb}$. to $5 \mathrm{lb}$. $8 \mathrm{oz}$. group. Again the latter was the smallest group 
TABLE 2

RELATION OF MEAN POST-NATAL BLOOD SUGAR TO BIRTH WEIGHT, EXCLUDING CORD-BLOOD DETERMINATION

\begin{tabular}{|c|c|c|c|c|c|c|}
\hline $\begin{array}{c}\text { Birth } \\
\text { Weight } \\
\text { (Ib. oz) }\end{array}$ & $\begin{array}{l}\text { No. of } \\
\text { Cases }\end{array}$ & $\begin{array}{l}\text { No. } \\
\text { of De- } \\
\text { termin- } \\
\text { ations }\end{array}$ & $\begin{array}{c}\text { Highest } \\
\text { Level } \\
\text { (mg.) }\end{array}$ & $\begin{array}{l}\text { Lowest } \\
\text { Level } \\
\text { (mg.) }\end{array}$ & $\begin{array}{l}\text { Mean } \\
\text { (mg.) }\end{array}$ & $\begin{array}{c}\text { Stand- } \\
\text { ard } \\
\text { Devia- } \\
\text { tions } \\
\text { (mg.) }\end{array}$ \\
\hline $\begin{array}{rr}\text { Under } & 3 \\
3-3 & 15 \\
4-4 & 15 \\
5-5 & 8\end{array}$ & $\begin{array}{l}6 \\
5 \\
6 \\
4\end{array}$ & $\begin{array}{l}33 \\
30 \\
40 \\
30\end{array}$ & $\begin{array}{r}107 \\
85 \\
96 \\
66\end{array}$ & $\begin{array}{l}18 \\
36 \\
18 \\
15\end{array}$ & $\begin{array}{l}47 \cdot 1 \\
56 \cdot 3 \\
45 \cdot 2 \\
34 \cdot 2\end{array}$ & $\begin{array}{l}14 \cdot 1 \\
11 \cdot 3 \\
13 \cdot 3 \\
12 \cdot 7\end{array}$ \\
\hline Total & 21 & 133 & 107 & 15 & $44 \cdot 4$ & 15.9 \\
\hline
\end{tabular}

in the series. Similarly the cord blood sugar showed no relationship to the birth weight (Table 3).

TABLE 3

RELATION BETWEEN CORD BLOOD SUGAR AND BIRTH WEIGHT

\begin{tabular}{|c|c|c|c|c|c|}
\hline $\begin{array}{l}\text { Weight } \\
\text { (lb. oz) }\end{array}$ & $\begin{array}{l}\text { No. of } \\
\text { Cases }\end{array}$ & $\begin{array}{l}\text { Mean } \\
\text { (mg.) }\end{array}$ & $\begin{array}{c}\text { Standard } \\
\text { Deviation } \\
\text { (mg.) }\end{array}$ & $\begin{array}{c}\text { Highest } \\
\text { Level } \\
\text { (mg.) }\end{array}$ & $\begin{array}{l}\text { Lowest } \\
\text { Level } \\
\text { (mg.) }\end{array}$ \\
\hline $\begin{array}{ll}\text { Under } & 3 \\
3-3 & 15 \\
4-4 & 15 \\
5-5 & 8\end{array}$ & $\begin{array}{l}6 \\
5 \\
6 \\
4\end{array}$ & $\begin{array}{l}73 \\
78 \\
62 \\
73\end{array}$ & $\begin{array}{l}27 \cdot 5 \\
28 \cdot 4 \\
30 \cdot 2 \\
25 \cdot 3\end{array}$ & $\begin{array}{r}100 \\
116 \\
84 \\
140\end{array}$ & $\begin{array}{l}56 \\
40 \\
44 \\
24\end{array}$ \\
\hline
\end{tabular}

The infants were divided into two groups, the moderately jaundiced and the severely jaundiced. The validity of this distinction will be referred to later. It was found that the severely jaundiced babies had a significantly higher blood sugar level than the moderately jaundiced (Table 4).

TABLE 4

RELATION OF BLOOD SUGAR TO SEVERITY OF JAUNDICE

\begin{tabular}{lccccc}
\hline & $\begin{array}{c}\text { No. of } \\
\text { Cases }\end{array}$ & $\begin{array}{c}\text { No. of } \\
\text { Deter- } \\
\text { minations }\end{array}$ & $\begin{array}{c}\text { Mean } \\
\text { (mg.) }\end{array}$ & $\begin{array}{c}\text { Standard } \\
\text { Deviation } \\
\text { (mg.) }\end{array}$ \\
\cline { 2 - 3 } $\begin{array}{l}\text { Severe jaundice } \\
\text { Moderate jaundice }\end{array}$ & 12 & 55 & $\begin{array}{c}54 \cdot 1 \\
41 \cdot 2\end{array}$ & $\begin{array}{c}11 \cdot 9 \\
10.4\end{array}$ \\
\hline
\end{tabular}

Eight infants in the present series were considered to be distressed (Table 5). Distress was assessed clinically by the presence of cyanosis, flaccidity, twitching or gasping respirations. One infant was excluded from Table 5 and the subsequent two

TABLE 5

RELATION OF MEAN POST-NATAL BLOOD SUGAR LEVEL TO NEONATAL DISTRESS

\begin{tabular}{|c|c|c|c|c|}
\hline & $\begin{array}{l}\text { No. of } \\
\text { Cases }\end{array}$ & $\begin{array}{l}\text { No. of } \\
\text { Deter- } \\
\text { minations }\end{array}$ & $\begin{array}{l}\text { Mean } \\
\text { (mg.) }\end{array}$ & $\begin{array}{c}\text { Standard } \\
\text { Deviation } \\
\text { (mg.) }\end{array}$ \\
\hline $\begin{array}{l}\text { Distressed } \\
\text { Non-distressed }\end{array}$ & $\begin{array}{r}8 \\
12\end{array}$ & $\begin{array}{l}35 \\
92\end{array}$ & $\begin{array}{l}50 \\
44\end{array}$ & $\begin{array}{l}11 \cdot 8 \\
12 \cdot 2\end{array}$ \\
\hline
\end{tabular}

tables. The mother of this infant was a diabetic and the case was excluded because of the known morbidity of such infants in the neonatal period. The blood sugar level of the distressed and the nondistressed groups showed no striking difference.

Seven infants in the series died (Table 6). Postmortem examination was carried out in five cases.

TABLE 6

RELATION OF MEAN POST-NATAL BLOOD SUGAR LEVEL TO DEATH OR SURVIVAL

\begin{tabular}{|c|c|c|c|c|c|c|}
\hline & & & $\begin{array}{l}\text { No. of } \\
\text { Cases }\end{array}$ & $\begin{array}{l}\text { No. of } \\
\text { Deter- } \\
\text { minations }\end{array}$ & $\begin{array}{l}\text { Mean - } \\
\text { (mg.) }\end{array}$ & $\begin{array}{l}\text { Standard } \\
\text { Deviation } \\
\text { (mg.) }\end{array}$ \\
\hline $\begin{array}{l}\text { Died } \\
\text { Lived }\end{array}$ &.. & .. & $\begin{array}{r}7 \\
13\end{array}$ & $\begin{array}{l}41 \\
86\end{array}$ & $\begin{array}{l}43 \cdot 1 \\
48 \cdot 2\end{array}$ & $\begin{array}{r}9 \cdot 5 \\
16 \cdot 5\end{array}$ \\
\hline
\end{tabular}

The cause of death in three was intranatal asphyxia and in the other two it was intracranial haemorrhage. The remaining two deaths were ascribed to intracranial injury on clinical grounds. There was no significant difference between the blood sugars of those who survived and those who died.

The relation of the blood sugar to distress was further investigated by noting the time at which the clinical manifestations of distress were most marked or death appeared imminent, and comparing the blood sugar level about this time with the previous mean (Table 7).

TABLE 7

BLOOD SUGAR LEVEL NEAREST TIME OF GREATEST DISTRESS OR DEATH

\begin{tabular}{|c|c|c|c|c|}
\hline No. & Result & $\begin{array}{c}\text { Previous } \\
\text { Mean } \\
\text { (mg.) }\end{array}$ & $\begin{array}{c}\text { Value at } \\
\text { Time of } \\
\text { Most } \\
\text { Distress } \\
\text { (mg.) }\end{array}$ & Difference \\
\hline $\begin{array}{l}1 \\
2 \\
3 \\
4 \\
5 \\
6 \\
7 \\
8\end{array}$ & $\begin{array}{l}\text { Lived } \\
\text { Lived } \\
\text { Lived } \\
\text { Died } \\
\text { Died } \\
\text { Died } \\
\text { Died } \\
\text { Died }\end{array}$ & $\begin{array}{l}60 \\
43 \\
70 \\
36 \\
48 \\
53 \\
61 \\
29\end{array}$ & $\begin{array}{r}36 \\
86 \\
107 \\
46 \\
37 \\
26 \\
18 \\
55\end{array}$ & $\begin{array}{l}-24 \\
-43 \\
-37 \\
-10 \\
-11 \\
-27 \\
-43 \\
-26\end{array}$ \\
\hline
\end{tabular}

The results showed no constant trend. Thirty-one readings of $30 \mathrm{mg} . \%$ or less were found in the series. The clinical condition at the time of these low levels has been considered. Only on four occasions was there an association between a blood sugar level of less than $30 \mathrm{mg}$. and clinical evidence of distress.

The liver glycogen content after death was estimated (Table 8). None of these infants had been fed. The figures are influenced to a considerable extent by the delay between death and the removal of the liver. This was occasioned by the necessity for obtaining permission from the parents. Allowing 
TABue 8

LIVER GLYCOGEN CONTENT AFTER DEATH

\begin{tabular}{|c|c|c|c|c|c|c|}
\hline No. & Maturity & $\begin{array}{l}\text { We } \\
\text { (Ib. }\end{array}$ & oz) & $\begin{array}{l}\text { Time } \\
\text { Survived }\end{array}$ & $\begin{array}{l}\text { Interval* } \\
\text { (hours) }\end{array}$ & $\begin{array}{l}\text { Result } \\
\text { (me \% }\end{array}$ \\
\hline $\begin{array}{r}1 \\
2 \\
3 \\
4 \\
5 \\
6 \\
7 \\
8 \\
9 \\
10\end{array}$ & $\begin{array}{l}28 \text { weeks } \\
28 \text { weeks } \\
28 \text { weeks } \\
36 \text { weeks } \\
40 \text { weeks } \\
40 \text { weeks } \\
30 \text { weeks } \\
36 \text { weeks } \\
34 \text { weeks } \\
40 \text { weeks }\end{array}$ & $\begin{array}{l}2 \\
2 \\
3 \\
4 \\
6 \\
6 \\
2 \\
5 \\
3 \\
6\end{array}$ & $\begin{array}{r}3 \\
0 \\
0 \\
14 \\
0 \\
8 \\
14 \\
4 \\
10 \\
10\end{array}$ & $\begin{array}{l}3 \text { days } \\
4 \text { days } \\
4 \text { bours } \\
41 \text { hours } \\
\text { S.B. } \\
1 \text { hour } \\
38 \text { hours } \\
22 \text { bours } \\
16 \text { hours } \\
25 \text { mins. }\end{array}$ & $\begin{array}{l}\text { Nil } \\
\text { Nil } \\
52 \text { hours } \\
\text { Nil } \\
16 \text { hours } \\
14 \text { hours } \\
70 \text { hours } \\
30 \text { hours } \\
16 \text { hours } \\
8 \text { hours }\end{array}$ & $\begin{array}{r}340 \\
45 \\
400 \\
33 \\
1,670 \\
2,500 \\
9 \\
40 \\
200 \\
1,748\end{array}$ \\
\hline
\end{tabular}

- The figure in this column denotes the interval that elapeed between the death of the infant and the determination of the liver glyoosen.

for this time lag the cases examined showed a depletion of liver glycogen which was well marked within 12 hours of birth.

\section{Discusion}

The mean value for the blood sugar in the first day of life is almost identical with that found by Norval (1950) using a similar technique. Norval's figure for the second day is $53 \mathrm{mg}$. as against $45 \mathrm{mg}$. in the present series. The difference may be due to the fact that the infants in this series received no feeds, or feeds of negligible sugar content on the second day. This would suggest that premature infants behave like full-term infants in that their blood sugar levels remain low until feeding is begun. Kugelmass, Berggren and Cummings (1933), van Creveld (1929) and Norval (1950) drew attention to the absence of symptoms with hypoglycaemia in newborn premature infants.

The absence of a connexion between the birth weight and the blood sugar level is common to the findings of all investigators. This is interesting in view of the fact that liver glycogen increases with maturity. Windle (1940) states that this is true for all mammals. Clogne, Welti and Pichon (1924) and Eufinger (1932) have shown that it is true for man. The premature infant is less well equipped to withstand carbohydrate deprivation than the full-term infant. This draws attention again to the significance of starvation in the production of low blood sugar levels. The absence of correlation with the birth weight indicates that even moderately large glycogen stores are depleted by starvation. Lund, quoted by Huggett (1941), states that embryonic glycogen appears to have a different constitution from adult glycogen. In this difference may lie some reason for the absence of relationship between the birth weight and the blood sugar. The increase in liver glycogen towards term is accompanied by a decrease in placental glycogen. This alteration in the placental glycogen is not reflected in the cord blood sugar, indicating that at birth the foetus has already assumed control over the blood sugar.

Van Creveld (1929) held that the blood sugar was low in premature infants because of functional immaturity of the regulating mechanism, in which he gave pride of place to the liver. He did so because of the low glycogen content of the liver in premature animals and because of the evidence that physiological jaundice indicated hepatic dysfunction. This view of physiological jaundice is now accepted (Smith, 1951). Further evidence of the inadequate excretory function of the liver in the newborn is found in the work of Yudkin, Gellis and Lappen (1949) and Mollison and Cutbush (1949) who found a marked delay in the excretion of bromsulphalein in the early days of life in normal newborn infants. No comparable studies have been made on premature babies. Halbrecht and Brzoza (1950) found no difference between the albumin-globulin ratio, serum Van den Bergh reaction, thymol and cephalin flocculation tests in premature and full-term infants. This conflicts with the common experience of the greater frequency of icterus in premature infants.

In the present series the severely jaundiced infants had higher blood sugar level than the moderately jaundiced. The distinction between the two groups was clinical and it must be accepted that the clinical assessment of jaundice is often made difficult by changes in the vascularity of the skin and by the presence of anaemia. Furthermore, many premature infants show some degree of jaundice. With these reservations the present work indicates that impairment of the excretory function of the liver is not necessarily accompanied by failure of carbohydrate control and that the liver glycogen stores are more important than theoretical failure of the release mechanism.

In the absence of large liver glycogen stores the maintenance of the blood sugar level is dependent on gluconeogenesis. This is controlled by the corticoids of the suprarenal. There is evidence that suprarenal function is deficient in the first few days, although it subsequently reaches adult standards. Talbot, Zygmuntowicz, Wood and Christo (1950) found that the corticoid excretion per unit body surface was constant throughout life, apart from the first few days when it was low. Venning (1950) found no rise in the corticoid excretion after A.C.T.H. injection on the second day. The circulating eosinophils were found to be low in the first two days by Lippman (1924) and Klein and Hanson (1950). The latter also found an inadequate response in the eosinophil count following injection of A.C.T.H. White and Sutton (1950) found that the eosinophils did not fall after injection 
of adrenalin in premature infants under $2,270 \mathrm{~g}$. weight. Desmond, Hild and Gast (1950) found no striking response in the blood sugar following adrenalin. Selye (1946) described the effect of stress on the blood sugar; a rise in the stage of alarm, fall during resistance and a further rise following exhaustion. The absence of a consistent glycaemic response to stress in the present series and in that of Liebe (1940) is confirmatory evidence of suprarenal hypofunction.

A further factor in the regulation of the blood sugar is insulin. Nakamura (1924) described an excess of islet cells in foetuses and newborn infants. Fisher and Scott (1934) found a gradual decrease in the insulin content of calf pancreas from the fifth antenatal month to the early post-natal period. Even then the insulin content was higher than adult levels. The effect of this is counteracted by the increased resistance of foetuses of all species to insulin. Hartman and Jaudon (1937) confirmed this to some extent in human newborn infants.

\section{Summary}

The blood sugar has been studied in premature babies in the first two days of life. Low levels have been found but these were not associated with abnormal symptoms. It is suggested that they are due to a low liver glycogen content, which is depleted by starvation. The endocrine control of the blood sugar in premature babies is discussed.
- My thanks are due to Dr. F. P. Hudson, consultant paediatrician, for encouraging me to perform this investigation in the Premature Baby Unit at Walton Hospital; to Dr. R. McLaren Todd, senior lecturer in child health, who revised the manuscript for publication; to $\mathbf{M r}$. R. Crosbie, B.Sc., and Miss P. Kennedy, B.Sc., who carried out the glycogen estimations, and to $\mathrm{Mr}$. $\mathrm{K}$. Kenyon, B.Sc., for the statistical analysis.

\section{REFERENCES}

Clogne, R., Welti, - and Pichon, M. (1924), Gynec. Obstet., 10, 23. Creveld, S. van (1929). Amer. J. Dis. Child., 38. 912

Desmond. M. M., Hild, J. R. and Gast, J. H. (1950). J. Pediat ., 37, 341 .

Eufinger, H. (1932). Mschr. Geburtsh. Gynäk., $92,272$.

Fisher, A. M. and Scott, D. A. (1934). J. biol. Chem.. 106, 305

Halbrecht, I. and Brzoza, H. (1950). Amer. J. Dis. Child., 79, 988.

Hartman, A. F. and Jaudon, J. C. (1937). J. Pediat., 11, 1.

Huggett, A. St G. (1941). Physiol. Rev. 21. 438.

Ketteringham, R. C. and Austin, B. R. (1938). Amer. med. Sci., 195, 318 .

Klein, R. and Hanson, J. (1950). Pediatrics, 6. 192

Kugelmass, I., Berggren, R. F. L. and Cummings, M. (1933). Amer J. Dis. Child., 46, 280.

Liebe, S. (1940). Mschr. Kinderheilk., 83,

Lippman, H. S. (1924). Amer. J. Dis. Child., 27, 473

Miller, H. C. and Ross, R. A. (1940).J. Pediat. 16, 473.

Mollison, $P$. L. and Cutbush, M. (1949). Archives of Disease in Childhood, 24,7 .

Nakamura, N. (1924). Virchows Arch., 253, 286.

Norval, M. (1950). J. Pediat., 36. 177.

Kennedy, R. L. J. and Berkson, J. (1949). Ibid, 34,342

Selye, H. (1946). J. Allergy., 17. 289.

Smith, C. A. (1951). Physiology of the Newtorn Infant. Oxford.

Talbot. N. B., Zygmuntowicz. A. N., Wood, M. and Christo, E. (1950) Proc. Ist Clinical A.C.T.H. Conference. Chicago, 1949, ed. J. R. Mote. London.

Venning E. (1950). Proc. 1st Clinical A.C.T.H. Conference, 'p. $\{25$. Chicago, 1949.

White, F. P. and Sutton, L. E. (1950). Pediatrics, 5, 876

Windle, W. F. (1940). Physiology of the Fetus. Philadelphia.

Yudkin, S., Gellis, S. S. and Lappen, F. (1949). Archives of Disease in Childhood, 24, 12. 